\title{
Duodenal Adenocarcinoma
}

National Cancer Institute

\section{Source}

National Cancer Institute. Duodenal Adenocarcinoma. NCI Thesaurus. Code C7889.

An adenocarcinoma that arises from the duodenum. Histologic variants include mucinous adenocarcinoma and signet ring cell carcinoma. 